\title{
From Protection to Poverty Reduction: A Review of Forestry Policies and Practices in Nepal
}

\author{
Ram B. Chhetri \\ Central Department of Sociology/Anthropology, TU., Kathmandu, Nepal \\ Email: rchhetri@info.com.np
}

\begin{abstract}
This paper examines the evolution of the policy and legislation in Nepal's forestry sector. The analysis reveals that there is a congenial environment for participatory forestry to contribute to the goal of poverty reduction in the country. While forestry in Nepal has mostly benefited the state authorities and the elite and did not give much consideration to the needs of the poor in the past, the policy and legislation in the country from the 1970s has evolved from being restrictive for public use, alienating the local people from the resources, to being open for improved utilization, increased participation of people and stakeholders, ensuring benefits to the local users, and regarding forestry as a potential vehicle for poverty reduction. The paper concludes that participatory forestry also stands out as a good example of Nepal's commitment towards decentralization and democratic principles.
\end{abstract}

Keywords: poverty reduction, forest policy, forestry sector, participatory forestry

\section{INTRODUCTION}

In Nepal, policy makers, planners as well as development professionals and researchers now recognize poverty as a formidable challenge facing the whole nation. It is no wonder that poverty reduction ranks amongst the highest goals set by the state in recent years (HMGN, 1998, 2002a) ${ }^{1}$. The current policy for poverty reduction hinges on four strategies, viz. i) Broad based economic growth; ii) Social sector development including human development; iii) Targeted programmes including social inclusion; and iv) Good governance (HMGN, 2002a:41). The Tenth Plan's forestry sector policy is in line with its overall policy framework. It emphasizes the promotion of conservation and the sustainable use of forest resources, development of forest product-based enterprises, adoption of participatory approaches and poverty reduction to be achieved by providing opportunities for income and employment for poor, women and disadvantaged people. A careful reading of the Tenth Plan reveals that almost all of the development sectors in the country today have become sensitive to

1 The Ninth Plan had used the term "poverty alleviation" whereas the Tenth Plan uses the term "poverty reduction". People tend to use these interchangeably also (e.g., see Warner's statement quoted above). The latter will be used in this paper. the calls for poverty reduction (HMGN, 2002b).

A greater policy focus on poverty reduction in Nepal now could be due to both internal and external pressures. There has been an increasing recognition in recent years of the fact that the planned development efforts carried out so far have had little impact on the lives of the poor. Meanwhile, various international, multilateral and bilateral agencies have also been showing concerns for the growing levels of poverty in the world, especially within the developing countries. Many of these agencies have now agreed to and adopted the "international development target of halving global poverty by the year 2015" (Warner, 2001).

Given that the current development agenda is focused on poverty reduction and ensuring sustainable livelihoods for the poor, a new perspective in forestry, as pointed out by Warner, is in order. She writes:

"For those working in forestry, the question raised is a critical one: what part can forests (and forestry) play in reducing poverty? This question requires a new perspective on forests and their use, in which success is measured not only by the amount of forest products harvested, export figures or revenue generated, but 
also by the contribution of forests in alleviating poverty" (Warner, 2001:3).

Although there has been an increased recognition in recent years of forestry's role in the livelihoods of the poor, most forestry projects and programmes around the world have been designed primarily with environmental objectives in mind. Even when socio-economic objectives are made manifest (and such projects are still an exception), projects seem to focus on "people in general" rather formulating any specific programme or strategy to address the needs of poor people.

Nepal is not an exception to this. In the past, the state authorities in Nepal seemed to have taken forests as a source of income for private individuals or at least the ruling class. Today, with the participatory mode of forestry being the major strategy in many countries, multiple potentials of Community Forests/Forestry (CF) are being explored and discussed in Nepal (Chhetri and Jackson, 1995; Malla, 1992, 2000). The questions that have been asked now include: Can forestry contribute towards poverty reduction? If yes, how? What sorts of attempts have been made thus far through policies, legislation and programmes? These are the main issues this paper intends to address.

This paper will document the main features of policy and legislative frameworks in forestry and discuss their implementation processes with a view towards exploring the linkages between forestry and poverty reduction in Nepal. The paper will also attempt to critique such provisions and procedures. But more importantly, it dwells on how the policy framework deals with the role of forests in meeting subsistence and income needs of local people, the rights of forest-dependent people (for subsistence) and their participation in management of local forests, generation of forest-related employment and enterprise development opportunities, benefits for local people from Non-Timber Forest Products (NTFPs) including wildlife and modalities about stakeholder participation in decisionmaking.

\section{ROLE OF FORESTRY IN POVERTY REDUCTION IN NEPAL}

In a developing country like Nepal, the role that forestry has played or can play in addressing poverty reduction is an important issue. The critical role of Community Forestry in particular and forestry in general in fostering social and economic development in Nepal's rural areas has already drawn some attention (Chhetri and Jackson, 1995; Malla, 1992). Malla proposed about a decade ago "as long as community forestry in Nepal is confined to the narrow objectives of meeting subsistence needs for fodder, fire wood and construction timber and excludes the domestic market, the potential contributions of community forestry to the socio-economic development process will not be fully realised" (Malla, 1992: 6). Similarly, Chhetri and Jackson, based on case studies in Sindhu Palchok and Kabhre Palanchok, argued that employment opportunities could be created through Community Forestry in the villages that "may have implications on the social and demographic processes too" (Chhetri and Jackson, 1995:111).

Some researchers have used the Sustainable Rural Livelihood approach in discussing the issues of livelihood and poverty among forest users groups in Nepal as well. This approach recognizes five forms of capital as crucial in talking about whether and how people's livelihoods have been and can be improved, viz.: natural capital, physical capital, financial capital, human capital and social capital (Shepherd and Gill, 1999; Bird, 2000). Those who use this model argue that poor people lack options for sustainable livelihoods and "options are created by possessions of capital assets" (Shepherd and Gill, 1999:12).

Policies and strategies for the reduction of poverty are laid out in various documents and legislation pertaining to a number of sectors at present. In the past, particularly during the 1970s, the focus was on integrated rural development, while in the 1980s, the focus shifted to meeting the basic needs. In the 1990s, Nepal moved along with the rest of the world in emphasising "sustainable development" and today, "poverty reduction" is considered to be the most critical and high-priority development objective. 
Forestry was a source of income for the elite and the governments during the 104 yearlong Rana regime. Large tracts of forested lands were part of the Birta grants made by the Rana governments to their kinsmen, loyal courtiers and other servants (for details on Birta land tenure, see Regmi 1978). The autocratic familial rule of the Ranas ended in February 1951. The Birta Abolition Act of 1959 finally brought an end to this pro-elite land tenure system instituted by the past rulers of this country. The role of forestry in poverty reduction could not have been favourable at all when the Birta system prevailed (most of the Birta lands may have been forests to begin with) and when the state showed much interest in extracting income through the trade of forest products. The Nepali saying "Aakash ko fal, Ankha tari mar" (literally meaning, "A fruit in the sky; Stare at it and die!") which metaphorically refers to things that remain out of reach for a person or a group of people. This metaphor nicely captures the situation for the poor people in the past in regard to their lack of access to the valuable resources of the forests or their inability to accrue any direct benefits or income from them. Fortunately, things seem to have changed in recent years and the policies and practices in forestry today appear to be in their favour as well. This section attempts to analyse the process that led to this paradigm shift in forestry - one from exclusion of the people to that of moving the people to the centre stage (Gilmour and Fisher, 1991).

\section{Analysis of the Policy Framework}

It appears that the issue of the management of forests in the country with some policy device was given attention only towards the beginning of the $20^{\text {th }}$ century. Collier's paper written at that time contains one of the first documented summaries of the then government's forestry policy, revealing how the rulers were more concerned about clearing forests for increasing farmlands and earning income through the timber trade (Collier, 1928). "The forest policy in Nepal took a turn only in the 1950s with the promulgation of the Private Forest Nationalization Act 1957" (Chhetri, 2004a).

The forestry sector policy in Nepal, from the way it has evolved over time, can be divided into three broad groups, viz.: privatization (pre-1950), nationalization (1957 and up to the mid-1970s) and community orientation (Graner, 1997; Hobley and Malla, 1996), which began in the late 1970s with the introduction of the Community Forestry $(\mathrm{CF})$ concept. If we look at the government policies in the years after the 1950s as expressed in government's periodic plans, we find that, while the emphasis in the 1950s was on protection, in the 1960s it was on scientific management. Participation of communities or popular participation in forestry was not recognized or was given only lip service until the middle of the 1970 s. It was only in the late 1970 s that the current mode of people-oriented forestry began in reality (based on a provision for "community" forestry in the Forest Act 1961). It should be pointed out that the idea of involving people was not adopted readily or simultaneously by all of the departments within the forestry sector.

As noted above, forestry in the past (i.e. until the 1970s) mostly benefited the state authorities and the elite in the country. The policies and legislation on forests did not give serious consideration to the needs of the poor, let alone involve them in the conservation and management of the country's valuable natural resources. Elites were encouraged by the state to reclaim forestlands by providing tax exemptions. No documented policies provide evidence of a genuine concern towards the poor until the first half of the $20^{\text {th }}$ century.

The current forestry policies, in contrast, have been acclaimed for their "popular orientation" because these now talk about meeting people's basic needs for forest products and also involving them in the protection and management of forests. Notwithstanding the progressive nature of the existing forest policies in Nepal, it should be conceded that the definition of "basic needs" is rather limited. In addition, the concept of people's participation is still ambiguous and perpetuates a gap between the "rhetoric and realities of people's participation" in conservation and development programmes (Chhetri, 1999). Besides, actual practice of policy-making in Nepal does not seem to be an open process that would allow for wider public debate and participation. These are areas in which change would be desirable in the future. 
Although the 1970s heralded the beginning of people-oriented forestry, it was during the 1970 s itself that the government began the creation of national parks which alienated the locals from access to the forests in their proximity. The forests brought under the protected area system excluded communities or people from management decision-making and refused to grant them their traditional use rights to forests in their proximity. In the forestry that is subsumed under the Protected Area (PA) system in Nepal, this began to change only after the Annapurna Conservation Area Project (ACAP) was conceived (in the mid 1980s) and implemented along the principles of Integrated Conservation and Development Programme (ICDP). Today, the policy for the PA system in general has taken a progressive turn after the introduction of the concept of Buffer Zone (BZ) management, which has created a space for the local communities to be involved in protection and management of forests surrounding the PAs or National Parks.

Under the heading "Policy and Implementation Strategy" within the section on Land Reform and Management (HMGN, 1998:282-289), the Ninth Plan document states that it expects to bring "progress in agricultural sector and to increase employment and income of landless and small farmers by increasing their access to land" (HMGN, 1998:284). A careful reading of the above section would convince anyone that the Plan fails to specify how the access to land for the poor is to be made possible. The landless and small farmers (read as poor) are in focus, which is a good sign. But how their access to the essential resources, including land, would be guaranteed still remains unclear. The Tenth Plan seems to present an improvement, since it aims to "ensure sustainable land use and management ...and increase access of the poor to land resources and ensure effective utilization through enhancement of their skills" (HMGN, 2002a: 45).

It is also important to mention the recent declaration made by the government about the emancipation of Kamaiyas (bonded labour households). This is certainly a progressive social reform policy with a noble goal. However, the irony is that its declaration to emancipate the Kamaiyas has resulted in relegating many of them from the 'frying pan into the fire' because of the government's ad hoc decision (rather than looking at the problem in a holistic way). The Kamaiyas are now free from their landlords, but they have no income source and no access to any resources for making a living (Chhetri, 2005). Anecdotal evidence from the field indicates that many of the 'freed Kamaiyas' have entered the forests and set up temporary shelters for themselves in government forest lands in the Mid- and Far-Western Terai. Resettlement of the 'freed Kamaiyas' as mentioned in the Tenth Plan remains a rhetoric so far.

Notwithstanding some weaknesses in the policies and approaches to poverty reduction in general, the way in which forestry policy (in forestry and related sectors) has evolved over the years in Nepal seems to have gradually increased the opportunities for local communities to share costs as well as benefits from the conservation and use of natural resources in the country. In general, the policy environment today appears favourable for the forestry sector to make a direct impact on poverty reduction processes in the country. The Master Plan for Forestry Sector (MPFS) policy objective aims to: (i) meet the people's basic needs for forestry products (firewood, fodder, leaf litter, etc.) on a sustainable basis, and (ii) protecting and managing forests through people's participation. Such provisions should be sufficient to argue that the forests policy in Nepal has been pro-poverty reduction at least since the MPFS came into force in 1988. It should however, be noted that the term "poverty reduction" is not mentioned in the objectives of the forestry sector policy documents. But the way that $\mathrm{CF}$ and Leasehold Forestry (LHF) programmes have been mandated to meet the basic needs of local farmers (specified as poor households in the case of LHF), gives us some grounds to argue that the policies have been progressive and open in this regard. That is, the current policy environment in forestry and related sectors is favourable to any innovative endeavours (as programmes, projects or activities) aimed at addressing the issues of poverty reduction in Nepal.

\section{Analysis of Acts and Regulations}

A discussion of forestry legislation in the historical context is to be found in various publications (Gautam, 1993; Graner, 1997; 
Talbott and Khadka, 1994; Regmi, 1988). Talking about the history of forestry legislation in Nepal, Gautam stated that the "legislation evolved from simple indigenous codes of practices to the present day externally influenced legislation" (Gautam, 1993: 300). Until 1957, forestry legislation in Nepal was to be found in the forms of government deeds, orders, circulars, etc. Regmi (1988) mentions a number of such historical documents, including a discussion of Kathmahals. The Legal Code of 1854 enacted during the reign of King Surendra is often cited as the first legislation to have made provisions related to forestry (Regmi, 1988). From the discussion of a provision called "Rukh Katnya" (cutting trees), it becomes evident that the Rana rulers in those days were mainly interested in the trade of timber, be it from national forests or from forests under Birta tenure (Gautam, 1993; Regmi, 1988).

A careful analysis of historical accounts during the $19^{\text {th }}$ century reveals that forestry was pro-elite and forests in the Terai region in particular yielded revenue to the government and income to the elite through export of timber and other products to India. Timber was floated down in boats or rafts to India through the major rivers (Regmi, 1988). Kathmahals existed in different places in the Terai. Documents also indicate that logging operations and trading of timber was common and the then governments readily approved such practices (Regmi, 1988).

In spite of the indiscriminate felling of trees (already occurring during the $19^{\text {th }}$ century) to meet the demands for timber across the border in India (for use as railway sleepers), Collier remarked towards the beginning of the 20th century: "Nepal's forests form the most important part of the great Himalayan timber belt stretching from the Indus to Sikkim" (Collier, 1928). The amount of this green wealth of the country is still considerable and the governments in Nepal have been making attempts to protect and conserve such resources through various legislative measures.

Since the 1950s, forestry legislation in Nepal has evolved from being restrictive for public use, and alienating the local people from the resources to being open for improved utilization, increasing participation of people and stakeholders, and ensuring benefits to the local users. The Private Forest Nationalisation Act 1957 (2013 BS) was the first forestry legislation enacted by the Nepali government. As stated already, before this act came into force, legal provisions concerning forestry sector were either included in other sectoral legislation or came in the form of government deeds, orders, circulars, etc.

The Private Forest Nationalisation Act 1957 should be considered an important turning point in the recent history of forestry legislation in Nepal since this act, for the first time, intended to set up an effective protection and management system for the country's forests. The large tracts of forests in the Terai held under Birta as well as other types of ownership were declared national property as steps towards that end. Thus, this act was primarily concerned with bringing an end to indiscriminate felling of trees in the Terai forests and the unregulated trade of timber with a view to check further degradation of forests in the country. In short, it could also be argued that this act should get credit for bringing an end to the monopoly of elites on forest resources and for making it possible to take steps towards the redistribution of forests to communities in the years since the late 1970s.

The CF programme, which began in the late 1970s, explicitly expressed a concern for meeting the subsistence needs of local farmers for firewood, fodder, leaf litter and some small timber for agricultural implements. In the years following, $\mathrm{CF}$ and other participatory forestry programmes have also incorporated local development objectives.

The Forest Act 1993 and the Forest Rules 1995 are considered to be quite progressive instruments, than the Master Plan itself. BZ Management Rules and Conservation Area Management Rules are aimed at involving local people in forest resources management within and around PA system.

Forest Act and Forest Rules have also laid down provisions related to private forestry. Private forests would benefit the wealthier farmers who can afford to devote some of their land to this purpose. But this may reduce pressure on $\mathrm{CFs}$ and Government Managed Forests (GMFs). Perhaps the 
poorer households could also be ensured more benefits from forestry through a system of positive discrimination (i.e. providing them with better access to forest resources through participatory forestry).

Legislation is an important tool if it is complied with and enforced. It provides the legal instruments necessary to put into effect many objectives of the forestry policy. It permits the translation of the objectives of a policy into specific legal provisions affecting the use of forests, forestland, and the way these resources enter into the life and development of communities, regions and the nation. However, one should not forget that legislation only provides a broad framework for implementing policy. Since policy objectives change and evolve as the years go by, new laws must be enacted frequently or older versions revised or abrogated to be consistent with the change. The best test of whether policy and legislation in forestry have created adequate space for this sector to contribute towards poverty reduction is to examine how implementation has proceeded. The next section therefore, reviews the implementation of participatory forestry in Nepal.

\section{Implementation}

This part reports on how various forestry programmes, as envisaged in the relevant policies and legislation, are being implemented on the ground. While doing this, it will also point out any variances that exist between policy goals and implementation. A review of the reports of implementation work carried out by various agencies and projects on forestry will allow us to identify the existing issues on the subject. Each project or programme may have a number of "success stories" that could be invoked to bolster the argument that "forestry does have a critical role to play in reducing rural poverty". However, only selected programmes will be discussed here.

The $\mathrm{CF}$ programme has been implemented at the field level for more than 20 years. Leasehold Forestry (for poor households) has been in operation for about a decade and BZ management, by involving community groups, has also been implemented since the early 1990s. Conservation programmes with stated objectives of conserving environments while improving the economic condition of local people have been operating since the mid-1980s. There are other participatory natural resource management programmes, also being implemented in the country. Together, these programmes offer opportunities for local communities to benefit and make improvements in their livelihoods by way of their participation in the management and development of natural resources. Participatory forestry has a potential role to play in Nepal's bid to fight against poverty in rural areas. Some discussion of implementation practice is in order for assessing the role of forestry in poverty reduction in Nepal.

\section{Community Forestry: Beyond Meeting the Basic Needs?}

As of December 2005, there were 14,227 Community Forest User Groups (CFUGs) managing $1,185,565$ hectares of forest area involving 1,635,664 households in different parts of the country. The CF programme has not only become very popular among people all over the country, but its effectiveness and efficiency in balancing conservation and rural development have been recognized by planners, policy makers, researchers as well as villagers.

As discussed above, $\mathrm{CF}$ programme's basic mandate has been to meet the basic needs of the local people while conserving the forest resources of the country. Implementation experience from various parts of the country and studies (Chhetri and Jackson, 1995; Malla, 1992, 2000; Nurse et al., 2004) have shown that CF has the potential to go beyond just meeting the basic needs. It has also been argued that the Community Forestry programme "is essentially a strategy adopted to bring about socio-economic change and development in rural societies" (Chhetri, 1994a:23). Empirical evidence shows that many CFUGs have collected funds and used such resources in supporting locally prioritized developments activities like improving the physical conditions of local schools, village drinking water supply and many other development activities (Chhetri and Pokharel, 2000), giving a clear message that community-oriented forestry holds a potential for rural development as well as poverty reduction in Nepal. Empirical studies have concurred that $\mathrm{CF}$ can generate funds at the local level that can be spent on 
projects considered appropriate by rural communities. Such development works could also benefit the state by "reducing the burden on the government to undertake local development works" (Chhetri and Jackson, 1995: 112). In order to realise these potentials of $\mathrm{CF}$, the policy and legislation in the country will need to keep pace with the practices and the demands at the field level.

Researchers have asked, "Why aren't the poor people benefiting more from Community Forestry?" (Malla et al., 2003). Based on a detailed study at the users' group and the users' household level, the researchers have come up with some interesting diagnoses that should draw the attention of policy-makers and development professionals. The authors see a number of problems: of distribution (and treating the users as a homogenous group), of some products being sold for cash (and thus only those with money can access), and of the elite dominating the decision-making process. It will be necessary for the implementation of $\mathrm{CF}$ at the field level to be sensitive to such issues in order to maintain its popularity as well as to realise its potential of addressing poverty.

\section{Non-Timber Forest Products for Income Generation Activity}

In recent years there has been an increasing awareness about the importance of nontimber forest products (NTFPs) for household, community and national level economies. There has also been an increased concern about the conservation of forests and biodiversity (FAO, 1994). Researchers have also argued that the value of the NTFPs (use value as well as monetary value) can be higher than timber harvest or land conversion to pasture or agricultural land (Rogue, 1992).

Sustainable management of NTFPs is important because of their value as a perennial source of subsistence and income for local communities as well as for the conservation of biodiversity. Trading of NTFP products, both unprocessed and semiprocessed, is done within Nepal and internationally. It is estimated that about $65 \%$ of the total collection of NTFPs is exported to India (Rawal, 1993) and the total quantity exported amounts to 10,000 to
15,000 tons annually (Edwards, 1996). The total contribution of the NTFP trade to Nepal's national economy is estimated to be equivalent to US\$8.6 million per year $(\$ 1=$ Rs. 49 in January 1994, when Edwards made these estimates) (Edwards, 1996). Scholars have also discussed how NTFP collection and sale by local people has accrued a significant proportion of the annual household income of poor people in different parts of Nepal (ANSAB, 1999; Chhetri and Pokhrel, 2000; Edwards, 1996; Olsen, 1998; Olsen and Helles, 1997).

David Edwards, on the basis of a review of works on NTFPs and with information obtained from his own field observation, asserts that NTFPs bring benefits to the poorer ethnic groups and other disadvantaged people, including women, because these are frequently the people who collect and harvest such products for trade (Edwards 1996). He reveals that from the sale of one particular medicinal plant, Chiraita (Swertia chirayita), alone, the average annual income for a harvester was about Rs 12,000 (Edwards, 1996).

Another researcher, on the basis of empirical information from Gorkha, reports that NTFP collection "commonly provides $15-35 \%$ of the annual income of poor households in the northern and middle parts of the district..." (Olsen, 1998: 285). According to Olsen, these areas also have a higher incidence of poverty within the district, while the percentage of households involved in the collection of NTFPs is also significant (at least $25 \%$ or more). Studies like these make it evident that NTFP collection and the income from their trade have a high potential for improving the livelihoods of poor people in the rural areas of Nepal. Of course, the reviewers argued that there are weaknesses in the legislation and policy appertaining to this sector which warrant changes (Chhetri and Pokharel, 2000).

Income-generating activities have been part of $\mathrm{CF}$ implementation approaches in different parts of the country today. Similarly, improving livelihoods through Community Forestry (Malla, 2000) and or in combination with other conservation activities have received increased attention. In general, the implementation of various forestry programmes and conservation of other natural resources have adopted an 
integrated approach, i.e. of balancing conservation and development.

It is interesting to note that Churia hills Forestry Development Project (ChFDP) has spelled out one of its three major approaches at the field level to be to "alleviate poverty by creating alternative opportunities for (off-forest) income". The idea behind such off-forest IGA activities rests on the premise that the volume of forest product utilization needs to be controlled in order to achieve effective conservation. Empirical studies have, in contrast, argued that improved utilization of forests rather than 'non-use' can be more effective in raising local commitment towards conservation (Chhetri, 2000; Malla, 2000). Assuming a direct correlation between poverty and forest degradation (Ghimire, 1992) appears to be a simplistic argument (Chhetri, 2000, 2004). Therefore, as opposed to "reduced use or non-use" of forest products for conservation, studies have argued in favour of creating opportunities for individuals and households to make income from forestry, including through the sustainable management of NTFPs in community-managed forests (Chhetri and Pokharel, 2000; Edwards, 1996; Olsen, 1998).

\section{Leasehold Forestry: Reaching the Poor Households}

In 1998, the National Planning Commission declared Leasehold Forestry to be a priority programme for poverty reduction. The Ninth Plan reads, "support to poverty reduction will be provided by promoting leasehold forestry through the identification of policyrelated and legal problems seen in this sector" (HMGN 1998: 296). A total of 25 districts have been identified for implementing the Leasehold Forestry programme for poverty reduction while, according to a recent field document, 10 districts were already under this project by 1999 (Ohler, 2000). The gradual increase in the area under the Leasehold Forestry programme is reported to have gone through in the following manner, as reported by Ohler (2000: 3).

The HLFFDP project area gradually expanded from two districts in Fiscal Year 1992/3 (Kavre and Makawanpur), to four in FY 1993/4 (Sindhupalchok and
Ramechhap), to six in FY 1995/6 (Dhading and Dolkha), to nine in FY 1996/97 (Sindhuli, Chiwan and Tanahu), ten districts in FY 1998/99 (Gorkha) and 22 districts in 2005.

The objectives of the Hills Leasehold Forestry and Forage Development Project are: (i) raising the incomes of families in the hills who are below poverty line; and (ii) contributing to the improvement of the ecological conditions of the hills.

Leasing blocks of degraded forestland to groups of poor households has been the strategy followed in order to achieve the aforementioned objectives. It is expected that improved management, enrichment plantation and protection will result in improving the vegetative cover in such lands. Due to the guaranteed access to fodder and grass supply, the poor households are believed to earn benefits from livestock production (Ohler, 2000; Yadav and Dhakal, 2000).

\section{Participatory Management in Protected Areas}

Community or people's participation has become a modus operandi in protected area management, as well. For instance, Participatory Management has been adopted as an effective approach in Annapurna Conservation Area Project, Makalu Barun Conservation Area Project, etc. The BZ management in a number of National Parks and Wildlife Reserves have opened up opportunities for collaboration between the state authorities and the local people in achieving biodiversity conservation and community development goals.

A final evaluation of $\mathrm{BZ}$ development in Royal Bardia National Park found that the project was very successful in reaching the poorest households with its incomegenerating activities programme (Ira et al., 1999). The report presents the case of a Sarki man in the project area who was unable to meet the food requirements of his family for more than 3-4 months before his participation in the BZ management activities of the project. With a loan from his IGA group (sponsored by the project), he was able to buy a new shoe-sewing machine and that allowed him to earn enough to meet his family needs. This Sarki man told the evaluation team, "me and my family now 
have two meals a day" (Ira et al., 1999: 36), suggesting that the livelihood situation of his household had improved substantially as a result of his access to resources through the BZ Management Project. People in other
BZs or forestry projects may have similar experiences especially when "benefits" of forestry programme have percolated down to the individual household level and the poor in particular.

\section{EMERGING ISSUES AND FUTURE ACTIONS}

Poverty as a malaise is not confined to any particular region in the country; it prevails in all places with only slight variation. Whether policy and legislation should be differentiated in order to address the geographical/region-specific resources (i.e. between the Terai, Hills and the Mountains) was an issue raised in a review of CF policy and legislation in Nepal (Grosen, 2000). The reviews have emphasized the point that the comparative advantages of the geographical or ecological contexts should be given due regard while framing policies and legislation that determine the modalities for conservation, management and use of forest resources.

The forestry legislation stipulates that the proceeds from the sale of forest products are to be used by the CFUGs for the development of their $\mathrm{CF}$ first and then only on other works. Many CFUGs in the country have undertaken local development works, irrespective of this apparently constraining legislative provision. However, the full potential of $\mathrm{CF}$ and other participatory forestry programmes for addressing the plight of the poor remain regulated or hindered by such legal bottlenecks. Besides, a critical question today is: "Have the poor and disadvantaged people benefited from 'local/community level' projects completed by the CFUGs with their own funds? If 'yes', how? Or if 'not', what can be done to ensure that they too accrue benefits?" Empirical research in the future may give us a better understanding on this issue.

The community groups of all types managing forests under the participatory forestry programmes in Nepal today are not always homogenous groups; they tend to be heterogeneous in terms of social, cultural and economic facets. This heterogeneity has defined the power relations as well as the accessibility to some of the important resources for different groups of people at the village level. Given this, the issue of poverty reduction through forestry needs to be seen as something that is intricately linked to the way social, cultural, and economic relations have evolved over time among different groups of people in Nepal.

Some scholars have argued that Leasehold Forestry for the poor and Community Forestry should receive equal priority in legal terms (Yadav and Dhakal, 2000). I would add that all types of participatory forestry being implemented in the country today should be given equal importance by legislation and policy.

This review makes it evident that there are various types of resource management groups (including several within the forestry sector alone) created by different programmes and projects at the field level. Their objectives in general appear to be similar, i.e. supporting conservation and development through popular participation. A question that comes up is: is it possible to formulate unified policy and legislation in order to define the organization, functions as well as the expected roles of such groups in conservation and management of natural resources? How can such groups be made to become sensitive to gender issues and the needs of the poor among their members? These and similar questions about inclusion/exclusion should be of concern to policy- and law-makers.

\section{CONCLUDING REMARKS}

Policy and legislation in forestry have provided a friendly environment for involving local communities in sharing the costs as well as the benefits from all kinds of participatory forestry in practice. Of course,

some refinements to remove any existing ambiguities are always needed (see Chapagain et al., 1999; Chhetri and Pokharel, 2000; Grosen, 2000). In practice, the irony is that $\mathrm{CF}$ programme, which remain the most popular programme among 
participatory forestry efforts in Nepal, are also unable to address poverty or to reach the poor directly. This programme also holds potential and one way to encourage addressing the issues of poverty would be to relax regulations on NTFP management and enterprise development (Chhetri and Pokharel, 2000). But again, policy, laws and practice will need to create an environment in which resources would permeate down to the poor directly, rather than being held by the group or being distributed equally among the rich and poor (Malla, 2000). They have aptly inquired as to why the poor were not benefiting as much from $\mathrm{CF}$.

Forestry, along with agriculture, has been considered as the sector with a high potential to make contributions in bringing about positive socio-economic change in the country and among its people. The Ninth Plan, for instance, states, "agriculture and forest resources are the main basis of the Nepalese economy, which contribute to raising living standard of the majority of the people" (HMGN, 1998: 311). The Ninth Plan also emphasizes that "poverty reduction is not possible" in Nepal unless these sectors are well developed (ibid). Clear policy and enabling legislation are the fundamental basis for achieving the desired goals. The above analysis makes it evident that these are in place. Putting these into practice is of course another issue; genuine commitment from the government's side stands as a prerequisite for the same.

The implementation of participatory forestry in the country has resulted in allowing communities to undertake locally prioritized development projects. Perhaps such an outcome was not foreseen by the MPFS written in the 1980s. However, the subsequent policies and legislation in the country have been open to address the emerging issues and the forestry legislation and have remained resilient to the imperatives set by the country's socioeconomic and development contexts.

It is often said that "hariyo ban, Nepalko dhan", meaning that green forests are the wealth of Nepal. An examination of the policies and legislation in relation to forestry in Nepal reveals that the value of forests and other natural resources have "certainly not been underestimated by the planners and policy makers" (Chhetri, 1994a:19). Of course, as is made evident by the evolving policy and legislation as well as the practices with regard to forestry and its use, average Nepali people and the socio-economically deprived communities in particular were able to gain very little from the green wealth of the country in the past. Even today, it would be relevant to ask: "who has the real claim on this wealth? Who has benefited so far and who will benefit?" (Chhetri, 1994a: 19). The answers we get from history and current practice is simple: the rulers and elite benefited from forestry in Nepal in the past, but there are indications now that a wider sharing of benefits is becoming a possibility.

Community Forestry has been an evolving concept and practice in Nepal ever since its inception in the late 1970s. The programme remains popular and the forestry sector has given "increased attention and priority to the relevant community forestry policies and legislation, along with a process of iterative learning" (Chhetri, 1994b:19). This applies to other forms of participatory forestry as well. In general, at the level of policy and legislation as well as in the field practice, participatory forestry stands out as a good example of Nepal's commitment towards decentralization and democratic principles.

The ways in which the number of participatory forestry users groups have increased in the country today has a clear message: people in different parts of the country not only regard themselves as the primary stakeholders of the natural resources in this country but also are convinced that the current mode of conservation and management practices are sensitive to their day-to-day needs and have the potential to bring many more benefits including the reduction of poverty in rural Nepal.

Finally, it should be conceded that the Community Forestry programme, which is so popular in the field, is less successful in reaching the poor households. This may be true of participatory arrangements in some of the conservation areas as well. Some success stories of the real poor benefiting from the forestry programmes in BZs or Leasehold Forestry have a clear message: other participatory forestry programmes should also find ways to move down to the individual household or targeted groups 
within communities (that are heterogeneous in terms of caste/ethnic as well as economic backgrounds) in order to play a meaningful role in poverty reduction while conserving the forests.

\section{ACKNOWLEGEMENT}

This paper is based on a much longer report that I wrote for FAO. Mr. Harihar Sigdel and Dr. Yam Malla were co-authors of that report and both of them had provided useful inputs and information while preparing the report in question. I am thankful for their contributions.

\section{REFERENCES}

ANSAB. 1999. Socio-Economic and Institutional Impacts of Community Based Ecosystem Management Project in Humla, Nepal. Kathmandu: ANSAB and SEEPORT.

Bird, P. 2000. Livelihood, Equity and Gender Issues in Community Forestry: Gaining Perspective on Poverty, Issue Paper No. 8. Kathmandu: The Joint Technical Review Committee on Community Forestry.

Chapagain, D.P.; Kanel, K.R. \& Regmi, D.C. 1999. Current Policy and Legal Context of the Forestry Sector with Reference to the Community Forestry Programme in Nepal: A Working Overview. Kathmandu: SocioEconomic and Ethno-Political Research and Training/Forum for Protection of Public Interest.

Chhetri, R.B. \& Pokhrel, B.K. 2000. IGA Programme and NTFP Management in Community Forest Users Groups, Issue Paper No. 3. Kathmandu: The Joint Technical Review Committee on Community Forestry.

Chhetri, R.B. 1994a. Indigenous and Community Forestry Management Systems: Reviewing the Strengths and Weaknesses. In M. Allen (Ed.), Anthropology of Nepal: Peoples, Problems and Processes (pp. 19-35). Kathmandu: Mandala Book Point.

Chhetri, R.B. 1994b. Rural Communities and their Forests. Habitat Himalaya: Resources Nepal Newsfile, January-February 1994. Kathmandu: Resources Nepal.

Chhetri, R.B. 1999. The Rhetoric and Realities of People's Participation in Conservation and Development in Nepal: An Anthropological Perspective. In R.B. Chhetri and O.P. Gurung (Eds.), Anthropology and Sociology of Nepal: Cultures, Societies, Ecology and Development (pp. 192-211). Kathmandu: SASON.

Chhetri, R.B. 2000. Relationship Between Income Generating Activities and Conservation of Forest Resources: A Study in the Churia Forest Development Project Area. Kathmandu: Churia Forest Development Project/GTZ.

Chhetri, R.B. 2005. The Plight of the Tharu Kamaiyas in Nepal: A Review of the Social, Economic and Political Facets. In R.B. Chhetri, K.B. Bhattachan and B. Pokharel (Eds.), Occasional Papers in Sociology and Anthropology, Volume 9 (pp.22-46). Kathmandu: Central Department of Sociology/Anthropology, Tribhuvan University.

Chhetri, R.B. \& Jackson, W.J. 1995. Community Forestry for Rural Development in Nepal: Some Prospects and Problems. In H. Schreier, P.B. Shah and S. Brown (Eds.), Challenges in the Mountain Resource Management in Nepal: Processes, Trends, and Dynamics in Middle Mountain Watersheds (pp. 106-113). Kathmandu: ICIMOD.

Chhetri, R.B. 2004. Conservation and Development in Nepal: Examining the Linkages of Forests with Population Growth and Poverty. In Twenty Five Years of Community Forestry: Proceedings of the Fourth National Workshop on Community Forestry, (pp. 218-228). Kathmandu: Community Forestry Division, Department of Forest.

Collier, J.V. 1928. Forestry in Nepal. In Landon, P. (Ed.), Nepal (pp. 251-255). New Delhi: Asian Educational Services.

Edwards, D. 1996. Non-Timber Forest Products from Nepal: Aspects of Trade in Medicinal and Aromatic Plants. FORESC Monograph 1/96. Kathmandu: Forest Research and Survey Centre.

FAO.1994. Non-wood News, Vo.1. Rome: FAO

Gautam, K.H. 1993. Evolving Forest Legislation: Strengthening or Weakening Indigenous Forest Management? In D. 
Tamang, G.J. Gill and G.B. Thapa (Eds.), Indigenous Management of Natural Resources in Nepal (pp. 299-308). Kathmandu: Winrock International.

Ghimire, K.B. 1992. Forest or Farm? The Politics of Poverty and Land Hunger in Nepal. Delhi: Oxford University Press.

Gilmour, D.A. \& Fisher, R.J. 1991. Villagers, Forests and Foresters: The Philosophy, Process and Practice of Community Forestry in Nepal. Kathmandu: Sahayogi Press.

Graner, E. 1997. The Political Ecology of Community Forestry in Nepal. Saarbrücken, Verlag für Entwicklungspolitik.

Grosen, J. 2000. Policy and Legal Framework Issues, Issue Paper No. 11. Kathmandu: The Joint Technical Review Committee on Community Forestry.

HMGN. 1998. The Ninth Plan (1997-2002). Kathmandu: His Majesty's Government, National Planning Commission, Nepal.

HMGN. 2002a. The Tenth Plan (2002-2007). (Summary) Kathmandu: His Majesty's Government, National Planning Commission, Nepal.

HMGN. 2002b. The Tenth Plan (2002-2007). Kathmandu: His Majesty's Government, National Planning Commission, Nepal.

Hobley, M. \& Malla, Y. 1996. From Forests to Forestry, The Three Ages of Forestry in Nepal: Privatisation, Nationalisation and Populism. In M. Hobley (Ed.), Participatory Forestry: The Process of Change in India and Nepal (pp. 65-92). London: Overseas Development Institute.

Ira, G.C.; Uprety, L.P. \& Franks, P. 1999. Royal Bardia National Park Buffer Zone Development Project (Final Evaluation Report). Kathmandu: CARE Nepal.

Malla, Y.B. 1992. The Changing Role of Forest Resources in the Hills of Nepal. Canberra: Australian National University.

Malla, Y.B. 2000. Impact of Community Forestry Policy on Rural Livelihoods and Food Security in Nepal. Unasylva, 51 (202): 37-45

Malla, Y.B.; Neupane, H.R. \& Braney, P. 2003. Why Aren't Poor People Benefiting More from Community Forestry? Forest and Livelihood, 3(1): 78-90.

Nurse, M.; Khatri, D. B.; Paudel, D. and
Pokhare1, B. 2004. Rural Entrepreneur Development: A Pro-Poor Approach to Enterprise Development through Community Forestry. In Twenty Five Years of Community Forestry: Proceedings of the Fourth National Workshop on Community Forestry, (pp. 250-258). Kathmandu: Community Forestry Division, Department of Forest.

Ohler, F.M.J. 2000. The Impact of Leasehold Forestry on Livelihoods and Environment, Field Document 3/2000. Kathmandu: Hills Leasehold Forestry and Forage Development Project, FAO.

Olsen, C.S. \& Helles, F. 1997. Making the Poorest Poorer: Policies, Laws and Trade of Medicinal Plants in Nepal. Journal of World Forest Resource Management, 8: 137-158.

Olsen, C.S. 1998. The Trade in Medicinal and Aromatic Plants from Central Nepal to Northern India. Economic Botany, 52(3): 279-292.

Rawal, R.B. 1993. Herbs Plantation and Processing Company Limited: A Summary of Activities. FORESC Occasional Paper 2/93 (pp. 12-15). Kathmandu: MFSC.

Regmi, M.C. 1978. Land Tenure and Taxation in Nepal. Kathmandu: Ratna Pustak Bhandar.

Regmi, M.C. 1988. An Economic History of Nepal, 1846-1901. Varanasi: Nath Publishing House.

Rogue, C. 1992. Creating Conditions for Incentives for Local Biodiversity Conservation. In K. Courrier (Ed.), Global Biodiversity Strategy (pp. 79-95). World Resource Institute, IUCN and UNEP.

Shepherd, G. \& Gill, G. 1999. Community Forestry and Rural Livelihoods in Nepal: Issues and Options. London: ODI.

Talbott, K. \& Khadka, S. 1994. Handing it Over: An Analysis of the Legal and Policy Framework of Community Forestry in Nepal. Washington D.C.: World Resources Institute.

Warner, K. 2000. Forestry and Sustainable Livelihoods, Unasylva, 51(202): 3-12.

Yadav, R.P. \& Dhakal, A. 2000. Leasehold Forestry for Poor: An Innovative Pro-Poor Programme in the Hills of Nepal. Kathmandu: HMG Ministry of Agriculture/Winrock International. 